\title{
Evaluation of Babassu Meal in Feed for Layer Hens During the Growth Phase
}

http://dx.doi.org/10.1590/1516-635x160279-86

\section{Author(s) \\ Carneiro $\mathrm{MIF}^{\mathrm{I}}$ \\ Sakomura NK" \\ Malheiros EB" \\ Araújo JA" \\ Silva EP dall \\ Kawauchi IM" \\ Fernandes JBK \\ Sousa JRST de}

Universidade Estadual do Maranhão, Departamento de Zootecnia, Campus Cidade Paulo VI, São Luís, MA. Brasil

" Faculdade de Ciências Agrárias e Veterinária, Universidade Estadual Paulista, FCAV/ Unesp, Jaboticabal, SP. Brasil

\section{-Mail Adress}

Corresponding author e-mail address

E-mail: minezfc@yahoo.com.br

\section{ABSTRACT}

Studies were conducted to evaluate the nutritional value and inclusion levels of babassu meal (BM) in the diet of grower layer pullets in substitution to wheat meal. Digestibility, metabolism and growth trials were conducted. Twelve cecectomized roosters were used in the digestibility assay to determine the coefficients of standardized digestibility of amino acids (CSDAA). The metabolism trial was conducted with 30 adult roosters to determine the apparent metabolizable energy corrected for nitrogen (AMEn) of BM. A growth trial was performed to determine replacement levels of wheat midds by BM diet using 360 six-week-old commercial layer pullets. BM was included at the 0,75 and $150 \mathrm{~g} / \mathrm{kg}$ of BM, during grower and development rearing phases, respectively. Feed intake, body weight gain, and feed conversion were evaluated. BM AMEn was determined as 1,474 kcal/kg, on as-fed basis. The CSDAA determined for BM were below $88 \%$ for all AA. The inclusion of $\mathrm{BM}$ in the feed of grower layers (7-18 week) significantly decreased feed intake $(p<0.05)$, but significantly improved body weight gain and feed conversion ratio $(p<0.05)$ at $15 \%$ inclusion level. Considering the nutritional value and performance results, BM can replace wheat midds in diets of grower layer pullets.

\section{INTRODUCTION}

The evaluation of nutrient composition, level, and availability, as well as energy concentration and availability in alternative feed ingredients is essential for feed formulation and to reduce feed costs (Rostagno et al., 2007). In addition, the commercial availability and physical characteristics of these ingredients also need to be assessed (Belaver \& Ludke, 2004), because of their wide variability (Albino, 1991; Tucci et al., 2003).

There are many alternative feedstuffs sold in the market of the northeast region of Brazil, and these may aid the development of poultry production in the region if properly used (CARNEIRO, 2012). In the state of Maranhão, babassu (Orbignya ssp) by-products are widely available. This palm tree is planted in an area of 10 million hectares in that state (DESER, 2007). The babassu fruit has four components: the epicarp is the most external layers, and consists of fibers, representing $11 \%$ of the fruit; the mesocarp (23\%) is rich in starch and other substances; the endocarp accounts for $59 \%$ of the fruit; and the kernel (7\%) contains about $60 \%$ of oil. Babassu is planted mostly for oil production (Soler et al., 2007).

Babassu kernel production in Brazil reached 118,723 tons in 2005, and the state of Maranhão produced 111,730 tons or $94 \%$ of total Brazilian production (IBGE, 2006). Babassu meal (BM) is a by-product of oil extraction by chemical solvents or mechanical crushing (Teixeira, 
Carneiro MIF, Sakomura NK,

Malheiros EB, Araújo JA, Silva EP da,

Kawauchi IM, Fernandes JBK,

Sousa JRST de

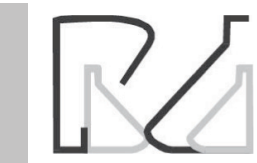

2003). BM is considered palatable and may potentially be used in animal feeds due to its protein, fat, and fiber levels (Teixeira, 2003).

There are few studies in literature on the inclusion of babassu meal (BM) in the feed of monogastric animals. Jatahy (1997) obtained higher birth weight in piglets from sows fed BM relative to wheat midds. Carneiro et al. (2009) found that up to $8 \%$ BM can be included in the diet of 22- to 42-d-old broilers with no detrimental effects on feed intake, weight gain, or feed conversion ratio. According to Santos Neta et al. (2011), the inclusion of up to $12 \%$ BM in starter broiler diets does not affect feed intake, weight gain, or feed conversion ratio.

Babassu meal composition is not very different from that of wheat midds, and therefore, could potentially replace the latter in development layer pullets.

The objective of this study was to evaluate the nutritional value and inclusion levels of babassu meal in pullet layer feeds during the development phase.

\section{MATERIALS AND METHODS}

Digestibility, metabolism, and performance trials were carried out. The digestibility and metabolism assays were performed with roosters at the Poultry Science Laboratory of the Department of Animal Science of FCAV/UNESP, Jaboticabal campus, Brazil. The live performance trial, aimed at evaluating BM inclusion levels for developing layer pullets, was carried out at the Poultry Experimental Unit "José dos Reis Ataíde", of the Agricultural Science Center of Universidade Estadual do Maranhão, São Luís, state of Maranhão, Brazil.

\section{Babassu meal origin and processing}

The evaluated BM was acquired from OLEAMA (Oleaginosas Maranhense), a company that processes babassu kernel in São Luis, MA, Brazil. The BM results from the industrial process of oil extraction from babassu kernel after grinding, cooking, pressing, filtration, and extraction with a solvent. Kernel processing involves laminating the kernel in slivers and successive immersions in hexane until oil is extracted. The solvent is continuously recovered by evaporation and distillation, and the resulting products are crude oil and pelleted babassu meal.

\section{Chemical and energy composition}

In order to determine the chemical and energy composition, the acquired BM was analyzed for dry matter (DM), nitrogen $(\mathrm{N})$ and $\mathrm{N}$ converted into
Evaluation of Babassu Meal in Feed for Layer Hens During the Growth Phase

crude protein $(C P=N * 6.25)$, ether extract (EE), neutral detergent fiber (NDF), and acid detergent fiber (ADF) at the Animal Nutrition Laboratory of FCAV/UNESP, Jaboticabal campus, according to the methods described by Silva \& Queiroz (2002). Gross energy (GE) was determined in adiabatic bomb calorimeter (1281, PARR Instrument, USA). Amino acid composition was determined by HPLC at the Laboratory Centro de Apoio Nutricional (CEAN) of Adisseo Brasil Nutrição Animal in Santa Maria, state of Rio Grande do Sul, Brazil.

\section{Determination of apparent digestibility coefficients of amino acids}

The standardized digestibility coefficients of BM amino acids were determined using the methodology of precise feeding (Sibbald, 1976), as described by Sakomura \& Rostagno (2007) with cecectomized adult roosters. In total, 12 Bovans White ${ }^{\circledR}$ roosters were individually housed in metabolic cages and distributed into two treatments with six replicates of one bird each. Treatments consisted of birds fed BM and fasted birds for the collection of endogenous and metabolic losses (EML).

Birds were initially submitted to 48-h fasting to empty their digestive tract. Birds of the EML treatment were fasted for further $48 \mathrm{~h}$ for excreta collection. The birds in the BM treatment were fed $40 \mathrm{~g}$ of BM by gavage directly in the crop, as described by Sibbald (1976), after which they were taken to the cages. Excreta collection was immediately started, using a collecting plastic bag. As a precaution, collecting trays were also placed under the cages. Excreta collection of the EML birds simultaneously started. Excreta were collected for $48 \mathrm{~h}$ after birds were fed. In order to prevent microbiological spoilage of the excreta, a maximum interval of $12 \mathrm{~h}$ between collections was adopted.

The collected excreta were identified per replicate, frozen, freeze-dried, and analyzed for DM and amino acid content, as previously described. Based on these analyses, BM intake, excreta output, and on the analysis of the endogenous fraction obtained from fasted roosters, the standardized digestibility coefficients of BM amino acids were calculated according to the equation described by Sakomura \& Rostagno (2007).

\section{Determination of BM energy values}

The methodology of total excreta collection, according to the protocol described by Sakomura \& Rostagno (2007), was used to determine digestibility coefficients and apparent metabolizable energy (AME) and apparent metabolizable energy corrected for nitrogen (AMEn) values. Thirty Bovans White ${ }^{\circledR}$ roosters 
were housed in galvanized iron cages and randomly allotted to two treatments (diets), with five replicates of two birds each. Diets consisted of a reference diet formulated to supply the birds' nutritional requirements (Rostagno et al., 2005), containing 3,050 kcal AMEn and $148 \mathrm{~g} \mathrm{CP}$ per $\mathrm{kg}$. The test diet consisted of $75 \%$ of the reference diet and 25\% BM, on as-is basis.

A 10-d experimental period, with five days of adaptation and five days of excreta collection, was applied. Trays lined with plastic were placed under the cages for excreta collection. One $\mathrm{g}$ ferric oxide per $\mathrm{kg}$ of diet was added to both feeds on the first and the last day of collection to allow identifying the first and last collection day. Excreta with no marker on the first day of collection and those with the marker on the last day were discarded. Excreta were collected twice daily. Total feed intake and total excreta output were determined at the end of the experimental period.

The collected excreta were identified per replicate, frozen, freeze-dried, and submitted to analyses. After drying, excreta samples were ground in a micro-mill and submitted to the laboratory, together with samples of the test and reference diets for DM, GE, and N determination, according to the methods described by

Table 1 - Ingredients and calculated composition of the experimental diets ( $\mathrm{g} / \mathrm{kg}$ )

\begin{tabular}{|c|c|c|c|c|c|c|}
\hline \multirow{2}{*}{ Ingredients } & \multicolumn{3}{|c|}{ 7-12 weeks } & \multicolumn{3}{|c|}{ 13-18 weeks } \\
\hline & 0 & 75 & 150 & 0 & 75 & 150 \\
\hline Corn grain & 618.0 & 618.8 & 620.3 & 689.1 & 691.2 & 694.0 \\
\hline Soybean meal 45 & 188.8 & 184.0 & 178.2 & 131.5 & 126.5 & 121.3 \\
\hline Wheat midds & 150.0 & 75.0 & 0.0 & 150.0 & 75.0 & 0.0 \\
\hline Babassu meal & 0.0 & 75.0 & 150.0 & 0.0 & 75.0 & 150.0 \\
\hline Dicalcium phosphate & 14.0 & 14.7 & 15.3 & 9.8 & 10.5 & 11.1 \\
\hline Soybean oil & 12.6 & 16.5 & 20.2 & & 2.8 & 5.3 \\
\hline Limestone & 10.5 & 9.5 & 8.5 & 12.7 & 11.7 & 10.7 \\
\hline Salt & 3.6 & 3.6 & 3.6 & 3.3 & 3.3 & 3.3 \\
\hline Vitamin premix $^{1}$ & 1.0 & 1.0 & 1.0 & 1.0 & 1.0 & 1.0 \\
\hline Choline chloride 60 & 0.7 & 0.7 & 0.7 & 1.0 & 1.0 & 1.0 \\
\hline Mineral premix ${ }^{2}$ & 0.5 & 0.5 & 0.5 & 0.7 & 0.7 & 0.7 \\
\hline DL-Methionine 99 & 0.2 & 0.6 & 1.0 & 0.5 & 0.5 & 0.5 \\
\hline L-Lysine HCL 78 & 0.0 & 0.0 & 0.5 & 0.4 & 0.7 & 0.7 \\
\hline BHT & 0.1 & 0.1 & 0.1 & - & - & 0.4 \\
\hline Total & 1000.0 & 1000.0 & 1000.0 & 1000.0 & 1000.0 & 1000.0 \\
\hline \multicolumn{7}{|l|}{ Calculated composition } \\
\hline AMEn (kcal/kg) & 2900 & 2900 & 2900 & 2900 & 2900 & 2900 \\
\hline Crude protein (g/kg) & 160.0 & 160.0 & 160.0 & 140.0 & 140.0 & 140.0 \\
\hline Crude fiber $(\mathrm{g} / \mathrm{kg})$ & 35.4 & 46.5 & 57.8 & 33.5 & 44.7 & 56.0 \\
\hline Lysine* (g/kg) & 6.2 & 6.2 & 6.2 & 5.5 & 5.0 & 4.8 \\
\hline Methionine (g/kg) & 2.6 & 2.9 & 3.0 & 2.5 & 2.6 & 2.6 \\
\hline Methionine + cystine (g/kg) & 4.9 & 5.1 & 5.0 & 4.7 & 4.6 & 4.6 \\
\hline Threonine (g/kg) & 5.2 & 4.8 & 4.5 & 4.5 & 4.1 & 4.1 \\
\hline Calcium (g/kg) & 8.3 & 8.3 & 8.3 & 8.0 & 8.0 & 8.0 \\
\hline Available phosphorus (g/kg) & 3.9 & 3.9 & 3.9 & 3.1 & 3.1 & 3.1 \\
\hline Sodium (g/kg) & 1.6 & 1.6 & 1.6 & 1.5 & 1.5 & 1.5 \\
\hline Chlorine (g/kg) & 2.6 & 1.6 & 1.6 & 2.4 & 2.4 & 2.4 \\
\hline Potassium (g/kg) & 6.7 & 6.2 & 5.7 & 5.8 & 4.8 & 4.8 \\
\hline
\end{tabular}

IVitamin premix (amount/kg product) - Vit. A - 2,666,000 IU, Vit. B1 - 600 mg, Vit. B2 - 2,000 mg, Vit. B6 - 933.10 mg; Vit. B12 - 4,000 mcg; Vit. D3 - 666.50 mg; Vit. E - 5,000 IU; Vit. K - $600 \mathrm{mg}$, folic acid - $333.25 \mathrm{mg}$, pantothenic acid - 5,000 mg, biotin - $20 \mathrm{mg}$, choline - 133,330 mg,

niacin - $13.333 \mathrm{mg}$, selenium - $100 \mathrm{mg}$, vehicle Q.S.P. - $1000 \mathrm{~g}$.

${ }^{2}$ Trace mineral premix (amount/kg product) -Mn - 150,000 mg, Zn - 100,000 mg, Fe - 100,000 mg, Cu - 16,000 mg, I - 1,500 mg *Formulation based on digestible amino acids 
Carneiro MIF, Sakomura NK,

Malheiros EB, Araújo JA, Silva EP da,

Kawauchi IM, Fernandes JBK,

Sousa JRST de

Silva \& Queiroz (2002). The coefficients of apparent digestibility and apparent metabolizable energy (AME) and apparent metabolizable energy corrected for nitrogen (AMEn) were calculated using the equations proposed by Matterson et al. (1965).

\section{Evaluation of babassu meal inclusion levels in the feeds}

In the experiment, 360 Dekalb White $®$ layer pullets between seven and 18 weeks of age were used. Birds were individually weighed to obtain even weight distribution among the experimental units, and allotted according to a completely randomized experimental design to three treatments with six replicates of 20 birds each. Treatments consisted of iso-energy and isoprotein diets containing 0,75 or $150 \mathrm{~g} \mathrm{BM} / \mathrm{kg}$. BM was added at the expense of wheat midds.

Feeds were formulated according to the birds' nutritional requirements and feedstuff (corn, soybean meal, wheat midds, oil, phosphate, and limestone) composition proposed by Rostagno et al. (2005) and the BM composition determined in this study for the rearing (7-12 weeks) and development (13-18 weeks) phases, as shown in Table 1.

Body weight (BW, kg/bird), weight gain (WG, kg/ bird), feed intake ( $\mathrm{Fl}, \mathrm{kg} / \mathrm{bird}$ ) and feed conversion ratio $(F C R, \mathrm{~kg} / \mathrm{kg}$ ) were determined. Birds were weighed in the beginning and at the end of each phase to calculate weight gain. Feed offer and feed residues of each experimental unit were recorded per phase to determine average feed intake. Feed conversion ratio was corrected for mortality, as described by Sakomura \& Rostagno (2007).

The assumptions of error normality and homoscedasticity were tested by tests of Cramer-vonMises and Levene, respectively, at $P<0.05$. As data were quantitative, orthogonal contrasts were evaluated, considering linear and quadratic effects. Statistical analysis was carried out using $S A S \otimes$ software package (version 9.1, SAS Institute Inc., USA).

\section{RESULTS AND DISCUSSION}

\section{Babassu meal chemical and energy composition}

Chemical composition ( $\mathrm{g} / \mathrm{kg}$ ) and gross energy ( $\mathrm{kcal} /$ $\mathrm{kg}$ ) values of the evaluated BM are shown in Table 2 . The obtained CP values are close to those reported in literature of 173 (Embrapa, 1991), 175 (Valadares Filho et al., 2006), and 202 (Rostagno et al., 2011).
Evaluation of Babassu Meal in Feed for Layer Hens During the Growth Phase

The high crude fiber content determined (273.3 $\mathrm{g} / \mathrm{kg}$ ) was much lower than the $475.2 \mathrm{~g} / \mathrm{kg}$ reported by Rostagno et al. (2011), but close to the $25.93 \%$ value observed by Embrapa $(1991 ; 259.3 \mathrm{~g} / \mathrm{kg}$ ) and Silva $(2009 ; 295 \mathrm{~g} / \mathrm{kg})$. Other feedstuffs present similar crude fiber levels as BM, such as cottonseed meal $(249.3 \mathrm{~g} / \mathrm{kg})$, soybean hulls ( $327.0 \mathrm{~g} / \mathrm{kg})$, and sunflower meal $(257.2 \mathrm{~g} / \mathrm{kg})$, all of which are by-products of oil extraction. The obtained values of $674 \mathrm{~g} \mathrm{NDF/kg}$ and 475.5 ADF/kg are different from those reported by other authors (Valadares Filho et al., 2006; Silva, 2009; Rostagno et al., 2011).

Table 2 - Chemical and energy composition of babassu meal, expressed on DM basis ${ }^{1}$

\begin{tabular}{lcc}
\hline Chemical composition $^{2}$ & Unit & Level \\
\hline Dry matter & $\mathrm{g} / \mathrm{kg}$ & 911.4 \\
Crude protein & $\mathrm{g} / \mathrm{kg}$ & 182.1 \\
\hline Ether extract & $\mathrm{g} / \mathrm{kg}$ & 34.3 \\
Crude fiber & $\mathrm{g} / \mathrm{kg}$ & 273.3 \\
Ashes & $\mathrm{g} / \mathrm{kg}$ & 42.6 \\
\hline Neutral detergent fiber & $\mathrm{g} / \mathrm{kg}$ & 674 \\
Acid detergent fiber & $\mathrm{g} / \mathrm{kg}$ & 475.5 \\
Gross energy & $\mathrm{kcal} / \mathrm{kg}$ & 4321 \\
Calcium & $\mathrm{g} / \mathrm{kg}$ & 0.44 \\
\hline Total phosphorus & $\mathrm{g} / \mathrm{kg}$ & 9.33 \\
Potassium & $\mathrm{g} / \mathrm{kg}$ & 7.57 \\
Magnesium & $\mathrm{g} / \mathrm{kg}$ & 2.74 \\
Sodium & $\mathrm{g} / \mathrm{kg}$ & 6.58 \\
Chlorine & $\mathrm{mg} / \mathrm{kg}$ & 0.14 \\
Copper & $\mathrm{mg} / \mathrm{kg}$ & 0.02 \\
\hline Iron & $\mathrm{mg} / \mathrm{kg}$ & 0.16 \\
Manganese & $\mathrm{mg} / \mathrm{kg}$ & 0.21 \\
\hline
\end{tabular}

${ }^{1}$ An aliquot of a sample of $100 \mathrm{~kg}$ babassu meal was analyzed; ${ }^{2}$ All analyses were performed in duplicate.

Babassu meal EE content was higher than the 21.5 $\mathrm{g} / \mathrm{kg}$ observed by Rostagno et al. (2011). The different fat contents in BM may be due to different babassu kernel processing methods.

Gross energy content was close to that found by Rostagno et al. (2011; 4,207 kcal/kg), but was lower than the values obtained by Santos Neta et al. (2011) and Silva (2009), of 4,847 and 5,056 kcal/ $/ \mathrm{kg}$, respectively, which may be explained by the higher oil content remaining in the BM after babassu kernel processing. According to Rostagno et al. (2011), other feedstuffs present GE values similar or close to BM: rice meal, brewer's yeast, canola meal, cottonseed meal, peanut meal, sunflower meal, wheat midds, coconut 
meal, and soybean hulls. The difference between the GE values found in the present study relative to literature reports may be explained by the differences in the processes to obtain these by-products. This variability warrants further studies to determine the chemical composition of BM with higher accuracy.

\section{Determination of BM energy values}

Apparent metabolizable energy (AME), apparent metabolizable energy corrected for nitrogen (AMEn), and the coefficients of apparent digestibility of dry matter are shown in Table 3.

The obtained AME value was higher than that found by Rostagno et al. (2011, $1116 \mathrm{kcal} / \mathrm{kg}$ ), and lower than those reported by Embrapa (1991, 1932 $\mathrm{kcal} / \mathrm{kg})$ and Almeida et al. (2011, $1116 \mathrm{kcal} / \mathrm{kg})$. The metabolizable proportion of the analyzed GE (AMEn/ $\mathrm{GE}$ ) was $37.43 \%$, suggesting the low assimilation of energy during digestion and metabolism, with a loss of approximately $62.57 \%$ of GE. This indicates that the low efficiency of energy utilization by the birds may be related to the high fiber content of BM. Silva (2009) obtained $2650 \mathrm{kcal} / \mathrm{kg}$ AME when evaluating BM energy using the traditional method of total excreta collection in growing broilers. In that study, BM presented high ether extract content $(8.81 \%)$, which suggests higher oil retention in the meal after processing, thereby resulting in the higher $A M E$ value.

Table 3 - Means and standard error of apparent metabolizable energy (AME), and apparent metabolizable energy corrected for nitrogen (AMEn), and coefficient of apparent digestibility of dry matter (CADDM) of babassu meal.

\begin{tabular}{ll}
\hline Parameters & Values \\
\hline AME (kcal/kg as fed) & $1549 \pm 59.90$ \\
AMEn (kcal/kg as fed) & $1474 \pm 59.43$ \\
CAMDM $(\%)$ & $23.19 \pm 1.41$ \\
\hline
\end{tabular}

\section{Total and digestible amino acid values and coefficients of amino acid digestibility}

Total amino acid values, coefficients of standardized digestibility of amino acids (CSDAA) and digestible amino acid values are presented in Table 4. The coefficients were lower than those reported by Rostagno et al. (2011). In general, BM amino acid profile is lower compared with other protein feedstuffs, particularly relative to the limiting AA methionine and lysine.
The CSDAA of BM were lower than $88 \%$ for all $A A$. Among the essential $A A$, leucine presented the lowest average digestibility (62.18\%), and among the non-essential $A A$, the lowest average digestibility was presented by serine $(42.15 \%)$. The highest average coefficient of digestibility was obtained with phenylalanine $(87.72 \%)$ for the essential $A A$, and with cystine $(80.70 \%)$ for the non-essential AA. The coefficients of digestibility of babassu meal described by Rostagno et al. (2011) are close to those obtained in the present study.

Table 4 - Total amino acids (total AA), coefficients of standardized digestibility (CSDAA), and digestible amino acid (digestible $A A$ ) values of babassu meal' ${ }^{1}$.

\begin{tabular}{|c|c|c|c|}
\hline Amino acids & Total AA & CSDAA $^{2}$ & Digestible $\mathrm{AA}^{3}$ \\
\hline & $\mathrm{g} / \mathrm{kg}$ & $(\%)$ & $(g / k g)$ \\
\hline Methionine & 0.6 & 83.72 & 0.5 \\
\hline Cystine & 0.6 & 80.70 & 0.5 \\
\hline Met+Cys & 1.2 & 82.21 & 1.0 \\
\hline Lysine & 0.9 & 68.44 & 0.6 \\
\hline Threonine & 3.3 & 87.70 & 2.9 \\
\hline Arginine & 8.6 & 66.27 & 5.7 \\
\hline Isoleucine & 1.9 & 65.28 & 1.2 \\
\hline Leucine & 3.8 & 62.18 & 2.4 \\
\hline Valine & 3.3 & 63.22 & 2.1 \\
\hline Histidine & 0.7 & 63.17 & 0.4 \\
\hline Phenylalanine & 2.3 & 87.72 & 2.0 \\
\hline Tyrosine & 1.0 & 51.79 & 0.5 \\
\hline Serine & 2.0 & 42.15 & 0.8 \\
\hline Glycine & 1.9 & 74.67 & 1.4 \\
\hline Alanine & 0.6 & 64.82 & 0.3 \\
\hline Proline & 1.2 & 76.22 & 0.9 \\
\hline Aspartic acid & 3.7 & 50.10 & 2.0 \\
\hline Glutamic acid & 9.2 & 66.86 & 6.2 \\
\hline
\end{tabular}

${ }^{1}$ Values expressed on dry-matter basis; ${ }^{2}$ Coefficient of standardized digestibility of amino acids; ${ }^{3}$ Digestible amino acids

\section{Evaluation of babassu meal inclusion levels in the feeds}

The results of the statistical analyses and average feed intake, body weight, weight gain, and feed conversion ratio of growing layer pullets are shown in Table 5. The assumptions of error normality and homoscedasticity were tested and confirmed, as shown by the results presented in Table 5 . 
Table 5 - Feed intake (Fl, kg/bird), body weight (BW, kg), weight gain (WG, kg/bird), and feed conversion ratio (FCR, $\mathrm{kg} / \mathrm{kg}$ ) of growing layer pullets fed diets with different babassu meal levels.

\begin{tabular}{|c|c|c|c|c|}
\hline Levels & $\mathrm{FI}$ & BW & WG & FCR \\
\hline \multicolumn{5}{|c|}{7 to 12 week of age } \\
\hline $0 \mathrm{~g} / \mathrm{kg} \mathrm{BM}$ & 2.033 & 0.907 & 0.573 & 3.57 \\
\hline $75 \mathrm{~g} / \mathrm{kg} \mathrm{BM}$ & 2.102 & 0.906 & 0.571 & 3.68 \\
\hline $150 \mathrm{~g} / \mathrm{kg} \mathrm{BM}$ & 1.977 & 0.953 & 0.618 & 3.22 \\
\hline \multicolumn{5}{|l|}{ Statistics } \\
\hline F for treatment & $7.52 *$ & $3.58^{*}$ & $3.43 *$ & $5.38 *$ \\
\hline F for linear effect & & $5.25^{*}$ & $4.98^{*}$ & $5.71 *$ \\
\hline $\begin{array}{l}\text { F for quadratic } \\
\text { effect }\end{array}$ & $12.04^{*}$ & & & $5.05^{*}$ \\
\hline Levene test & $1.74^{\mathrm{NS}}$ & $3.71^{\mathrm{NS}}$ & $3.35^{\mathrm{NS}}$ & $4.66^{N S}$ \\
\hline CVM Test & $0.04^{\mathrm{NS}}$ & $0.38^{\mathrm{NS}}$ & $0.04^{\mathrm{NS}}$ & $0.03^{\mathrm{NS}}$ \\
\hline CV (\%) & 2.73 & 3.71 & 5.95 & 7.37 \\
\hline \multicolumn{5}{|c|}{13 to 18 week of age } \\
\hline $0 \mathrm{~g} / \mathrm{kg} \mathrm{BM}$ & 2.502 & 1.200 & 0.428 & 5.91 \\
\hline $75 \mathrm{~g} / \mathrm{kg} \mathrm{BM}$ & 2.433 & 1.206 & 0.409 & 6.01 \\
\hline $150 \mathrm{~g} / \mathrm{kg} \mathrm{BM}$ & 2.305 & 1.229 & 0.425 & 5.48 \\
\hline \multicolumn{5}{|l|}{ Statistics } \\
\hline $\mathrm{F}$ for treatment & $4.46^{\mathrm{NS}}$ & $0.17 \mathrm{NS}$ & $2.07^{\mathrm{NS}}$ & $0.69^{\mathrm{NS}}$ \\
\hline Levene test & $1.27^{\mathrm{NS}}$ & $0.11^{\mathrm{NS}}$ & $1.65^{\mathrm{NS}}$ & $0.03^{\mathrm{NS}}$ \\
\hline CVM Test & $0.54^{\mathrm{NS}}$ & $0.03^{\mathrm{NS}}$ & $0.05^{\mathrm{NS}}$ & $0.13^{\mathrm{NS}}$ \\
\hline CV (\%) & 5.28 & 11.84 & 3.44 & 11.57 \\
\hline \multicolumn{5}{|c|}{7 to 18 week of age } \\
\hline $0 \mathrm{~g} / \mathrm{kg} \mathrm{BM}$ & 4.451 & 1.200 & 0.858 & 5.19 \\
\hline $75 \mathrm{~g} / \mathrm{kg} \mathrm{BM}$ & 4.545 & 1.206 & 0.863 & 5.27 \\
\hline $150 \mathrm{~g} / \mathrm{kg} \mathrm{BM}$ & 4.298 & 1.229 & 0.908 & 4.74 \\
\hline \multicolumn{5}{|l|}{ Statistics } \\
\hline F for treatment & $2.92^{\mathrm{NS}}$ & $0.65^{\mathrm{NS}}$ & $2.19^{\mathrm{NS}}$ & $13.63^{*}$ \\
\hline F for linear effect & & & & $17.18^{*}$ \\
\hline $\begin{array}{l}\text { F for quadratic } \\
\text { effect }\end{array}$ & & & & $10.08 *$ \\
\hline Levene test & $0.75^{\mathrm{NS}}$ & $1.04^{\mathrm{NS}}$ & $1.30^{\mathrm{NS}}$ & $1.67^{\mathrm{NS}}$ \\
\hline CVM Test & $0.11^{\mathrm{NS}}$ & $0.04^{\mathrm{NS}}$ & $0.07^{\mathrm{NS}}$ & $0.03^{\mathrm{NS}}$ \\
\hline CV (\%) & 4.03 & 3.79 & 5.34 & 3.82 \\
\hline
\end{tabular}

CVM: Cramer-von-Mises test; CV: coefficient of variation

${ }^{*} p<0.05$

NS $p>0.05$

Dietary BM levels were studied by orthogonal contrasts, assuming linear or quadratic effects. Differently from polynomial regression, this analysis only determined if the variation in the response parameter was constant (linear) or variable (quadratic) as a function of increasing BM levels in the diet.
Therefore, in the phase of 7-12 weeks of age, the inclusion of $\mathrm{BM}$ in the feed had a quadratic effect $(p=0.0034)$ on feed intake, i.e., feed intake increased as BM dietary level increased. At the BM inclusion level of $150 \mathrm{~g} / \mathrm{kg}$, crude fiber increased from 35.4 to $57.8 \mathrm{~g} /$ $\mathrm{kg}$, reducing feed intake.

However, despite the reduction in feed intake, there was a positive linear effect on weight gain $(p=0.0414)$ and body weight $(p=0.0368)$ and a quadratic effect on feed conversion ratio $(p=0.0401)$, with the lowest feed conversion ratio obtained in the pullets fed $150 \mathrm{~g} / \mathrm{kg}$ BM. According to Gonzales-Alvarado et al. (2007) and Araujo et al. (2008), the inclusion of low fiber levels in the diet of growing layer pullets promotes the development of the digestive tract and therefore, has positive effects on nutrient digestion and efficiency of utilization.

During the development phase (13-18 weeks of age), feed intake, body weight, weight gain, and feed conversion ratio were not affected by the dietary inclusion of BM. The results show that increasing crude fiber levels to $5.60 \%$, as in the diet with the highest BM level, completely replacing wheat midds, did not affect feed intake and promoted the same performance as the pullets fed the diet with wheat midds. This indicates that babassu meal can completely replace wheat midds in the development diet of layer pullets.

Considering the entire period (7-18 weeks of age), feed intake, body weight, and weight gain were not influenced by dietary BM inclusion levels. However, there was a quadratic effect $(p=0.0063)$ on feed conversion ratio, indicating that birds responded to the treatments, with the lowest ratio obtained in pullets fed $150 \mathrm{~g} / \mathrm{kg}$ of BM. The higher fat content of this feed may have allowed better nutrient utilization, with consequent improvement of feed conversion ratio. A study showed that the economic limitation of fiber-rich ingredients occurs before biological limitation due to the need to add oil to the feeds (Silva et al., 2009a).

According to the nutritional value and performance results obtained in the present study, wheat midds can be replaced by babassu meal in the diet of development layer pullets.

\section{REFERENCES}

Albino LFT. Sistemas de avaliação nutricional de alimentos e suas aplicações na formulação de rações para frangos de corte [dissertation]. Viçosa (MG): Uversidade Federal de Viçosa; 1991

Almeida FO, Lopes JB, Farias LA, Paz da Silva MCB, Figueirêdo, AV, Aguiar A, Silva, MVF, Ramos, LSN, Uchoa, LM. Inclusão do farelo de babaçu em dietas de frango de corte: metabolismo. [CD-ROM]. Anais do $3^{\circ}$ Congresso Nordestino de Produção Animal; 2004; Campina Grande, Paraíba. Brasil. 1-3p. 
Araujo DM, Silva JHV, Miranda EC, Araújo JA, Costa FGP, Teixeira ENM. Farelo de trigo na alimentação de poedeiras semipesadas na fase de recria. Revista Brasileira de Zootecnia 2008; 37(1):67-72.

Bellaver C, Ludke JV. Considerações sobre os alimentos alternativos para dietas de suínos. Anais do Encontro Internacional dos Negócios da Pecuária; 2004; Cuiabá, Mato Grosso. Brasil. p.1-4. Disponível em: www.cnpsa.embrapa.br/sgc/sgc_publicacoes/publicacao_z7f18g4e. pdf

Carneiro APM, Pascoal LAF, Watanabe PH, Santos IB, Lopes JM, Arruda JCB. Farelo de babaçu em rações para frangos de corte na fase final: desempenho, rendimento de carcaça e avaliação econômica. Ciência Animal Brasileira 2009;10(1):40-47.

Departamento de Estudos Socioeconômicos. Secretaria de Agricultura Familiar. A cadeia produtiva do babaçu: estudo exploratório. Curitiba: DESER; 2007

Empresa Brasileira de Pesquisa Agropecuária. Tabela de composição química e valores energéticos de alimentos para suínos e aves. $3^{\text {a }}$ ed. Concórdia: EMBRAPA, Centro Nacional de Pesquisa de Suínos e Aves; 1991. 97 p. (Documentos 19).

Freitas BM, Zanella I, Carvalho AD, Raber MR, Brum Júnior, BS, Souza, JF, Franco, SS, Rosa, AP. Avaliação de complexo multienzimático com níveis de trigo para poedeiras na fase de recria. ARS Veterinária 2005; 21(1):1-6.

González-Alvarado JM, Jiménez-Moreno E, Valencia DG, Lázaro R, Mateos GG. Effect of type of cereal, heat processing of the cereal, and inclusion of fiber in the diet on productive performance and digestive traits of broilers. Poultry Science 2007; 86(8):1705-1715.

Instituto Brasileiro de Geografia e Estatística. Censo agropecuário 2006: Brasil, grandes regiões e Unidades da Federação; 2006. 777p.

Jatahy LM. de S. Potencialidades da torta de babaçu na alimentação de matrizes suínas gestantes. [monograph]. São Luís (MA): Universidade Estadual do Maranhão; 1997.

Matterson LD, Potter LM, Stutuz NW, Singsen EP. The metabolizable energy of feed ingredients for chickens. Storrs: The University of Connecticut, Agricultural Experiment Station; 1965. v.7, p.3-11.

Rostagno HS, Albino LFT Donzele JL, Gomes PC, Oliveira RFM, Lopes DC, Ferreira AS, Barreto SLT. Tabelas brasileiras para aves e suínos composição de alimentos e exigências nutricionais. $2^{a}$ ed. Viçosa: Universidade Federal de Viçosa; 2005.

Rostagno HS, Albino LFT, Donzele JL, Gomes PC, Oliveira RFM, Lopes DC, Ferreira AS, Barreto SLT, Euclides RF. Tabelas brasileiras para aves e suínos - composição de alimentos e exigências nutricionais. $3^{a}$ ed. Viçosa: Universidade Federal de Viçosa; 2011.
Rostagno HS, Bunzen S, Sakomura NK, Albino LFT. Avanços metodológicos na avaliação de alimentos e de exigências nutricionais para aves e suínos. Revista Brasileira de Zootecnia 2007; 36:295-304.

Santos Neta ER, Vaz RGMV, Rodrigues KF, Sousa, JPL, Parente, IP, Albino, LFT, Siqueira, JC, Rosa, FC. Níveis de inclusão da torta de babaçu em rações de frangos de corte na fase inicial. Revista Brasileira de Saúde e Produção Animal 2011; 12(1):234-243.

Sakomura NK, Rostagno, HS. Métodos de pesquisa em nutrição de monogástricos. Jaboticabal: Funep; 2007. 283p.

Sibbald IR. A bioassay for true metabolizable energy in feeding stuffs. Poultry Science 1976; 55(1):303-308.

Silva DJ, Queiroz AC. Análise de alimentos: métodos químicos e biológicos. Viçosa: UFV; 2002.

Silva, EP, Rabello, CBV, Dutra Júnior, WM, Loureiro, RRS, Guimarães, AAS Lima, MB, Arruda, EMF, Barbosa-Lima, R. Análise econômica da inclusão dos resíduos de goiaba e tomate na ração de poedeiras comerciais. Revista Brasileira de Saúde e Produção Animal 2009;10(7):774-785a.

Silva EP, Silva DAT, Rabello CBV, Lima RB, Lima MB, Ludke JV. Composição físico-química e valores energéticos dos resíduos de goiaba e tomate para frangos de corte de crescimento lento. Revista Brasileira de Zootecnia 2009;38(6):1051-1058b.

Silva, EP, Rabello, CBV, Lima, MB, Loureiro, RRS, Guimarães, AAS, Dutra Júnior, WM. Valores energéticos de ingredientes convencionais para aves de postura comercial. Ciência Animal Brasileira 2009; 10(1):91100c.

Silva RF. Avaliação nutricional da torta de babaçu em dietas para frangos Label Rouge. [dissertation]. Goiânia (GO): Universidade Federal de Goiás; 2009.

Soler MP, Vitali AA, Muto EF. Tecnologia de quebra do coco babaçu (Orbignya speciosa). Ciência e Tecnologia de Alimentos 2007;27(4):717-722.

Teixeira MA. Estimativa do potencial energético na indústria do óleo de babaçu no Brasil. Anais do 4th Encontro de Energia no Meio Rural; 2000; Campinas, São Paulo. Brasil. 2003. Disponível em: <http://www. proceedings.scielo.br/scielo.php?script=sci_arttext\&pid=MSC0000000 022000000200045\&lng=en\&nrm=iso>.

Tucci FM, Laurentiz AC, Santos EA, Rabello CBV, Longo FA, Sakomura NK. Determinação da composição química e dos valores energéticos de alguns alimentos para aves. Acta Scientiarum. Animal Sciences 2003;25(1):85-89.

Valadares Filho SC, Rocha Júnior VR, Cappelle ER. Tabelas brasileiras de composição de alimentos para bovinos. Viçosa: Unversidade Federal de Viçosa; 2006. 
